Jumrah, Developing An Intensive Course Model...

\title{
DEVELOPING AN INTENSIVE COURSE MODEL IN IMPROVING ENGLISH LANGUAGE SKILLS OF STUDENTS OF EARLY CHILDHOOD ISLAMIC EDUCATION DEPARTMENT (PIAUD)
}

\author{
Jumrah \\ UIN Mataram, Indonesia \\ E-mail: jumrah@uinmataram.ac.id \\ DOI: $\underline{10.26858 / \text { ijole.v1i1.7435 }}$
}

\begin{abstract}
Mastery of foreign languages is one of the important demands at all levels of education today. This has been demonstrated by government regulations that make English subjects a compulsory subject for students to learn from elementary school to higher education, especially after the application of the KKNI curriculum, English courses have become national subjects for all study programs despite scientific disciplines taken is not related to English. The Early Childhood Islamic Education (PIAUD) study program at State Islamic University of Mataram also makes English Language Courses a compulsory subject that must be taken by students in the first semester. Based on the results of observations and pre-test results conducted by researchers, the English language skills of PIAUD study program students are very low. Almost all PIAUD students are still at the beginner level. Therefore, this study aims to: first, to produce an intensive course model that can improve English language skills of PIAUD Study Program students, second, to produce teaching materials used in intensive courses that can improve the English language skills of PIAUD Study Program Students. This study uses a descriptive approach with the aim of describing the object of research or the results of research. The data is collected through tests, questionnaires, and interviews. The results of the study were then analyzed by normalized gain measurements and getting the Pretest value for this trial was 66.3 while the post test results were 84.6 so that the gain obtained was 0.28. This value has met the requirements and it can be concluded that the instructional materials made have a positive impact on improving students' English skills.
\end{abstract}

Keywords: Intensive Course Model, English Skill, Teaching Material, Student's Book, Teacher's book

\section{INTRODUCTION}

The low level of foreign language skills of students is a problem faced by almost all universities in Indonesia, whereas English is one of the international languages that plays a very important role in communicating with the outside world. Furthermore, the existence of the Asean Economic
Community (MEA) agreement made the map of labor competition even tighter. Competition to fight for job vacancies not only comes from fellow Indonesian workers, but also with workers from other countries in ASEAN (Rafiq, 2017).

Mastery of foreign languages is one of the important demands at all levels of 
education. English is an important international language that can connect people to the world in various aspects including aspects of education. This has been demonstrated by government regulations that make English subjects a compulsory subject for students to learn from elementary school to higher education, especially after the application of the KKNI curriculum, English courses have become national subjects for all study programs despite scientific disciplines taken is not related to English, this is show how important, mastering foreign language especially English language (Sri,2012).

Mastery of foreign languages is one of the important demands at all levels of education today. With the enactment of Indonesia as a member of the AEC (ASEAN Economic Community), it is a very strong reason why foreign languages must be mastered. Therefore, it is fitting for the generation of the nation to be more advanced in terms of science and technology which is supported by the mastery of good and correct language.

\section{LITERATURE REVIEW}

\section{Intensive English Course model (intensive English language course)}

A course is a learning process about knowledge or skills that is held in a short time by an institution / organization that is oriented to the needs of the community and business / industry(Mustafa, 2012). According to the Ministry of National Education Number 22 of 2006 explained that English is an international language that is used to convey ideas, thoughts, opinions, feelings, and also to respond to or fulfill needs in the workplace / industry. Based on this understanding, it can be concluded that English language courses are competency development activities related to attitudes, knowledge, language skills to express opinions derived from feelings, thoughts needed by individuals to do a task or work better to face the challenges of the present and future.

Abdulaiz (2017) Explained that intensive English courses have the purpose of the learning provided, Here are some of the goals of English courses:

1) Communicate using English well and fluently.

2) Understand and explore 4 basic aspects, namely writing, reading, speaking and listening properly and correctly.

3) Able to use English in daily life (minimum basic English)is preparing students who want to continue their studies abroad

Djuju (2016) explained that the minimum standards for the procedure for holding an Intensive English Course are as follows:

1) Standard content

The content standard is the material scope and level of competence as outlined in the criteria for graduate competence, study material competencies, subject competencies, and learning syllabus that must be met by learners at the level and type of education in the PNF Program.

2) Standard process

Process Standards are national education standards relating to the implementation of learning in an educational unit to achieve the competency standards of graduates of English language courses. Program organizers must have or make lesson plans:

\section{3) Educator standards}

In the implementation of the program the institution must also pay attention to matters 
in the criteria that the educator must have, namely:

a) The English language course program must have educators who meet competencies in accordance with the standards set.

b) Educators of English language course programs must attend relevant quality improvement training.

c) Education staff in English language courses should have competencies in accordance with what is required in their fields of work.

d) Education staff in English language courses should take part in relevant quality improvement training.

\section{4) Standard facilities and infrastructure}

Standards for facilities and infrastructure are national education standards relating to minimum criteria about study rooms, places to exercise, places of worship, libraries, laboratories, workshops, playgrounds, places to create and recreation, and other learning resources, which are needed to support the learning process.

\section{5) Standard of assessment}

The educational assessment standard is the national education standard relating to mechanisms, procedures, and instruments for the assessment of learning outcomes in English language courses.

\section{English Competence}

Competency in general is "competence refers to one 's underlying knowledge of a system, event, or fact. It is the nonobservable ability to do something, to perform something."(Brown, 2001)A more specific definition of language competence, which is "in reference to language, is competence is the underlying knowledge of the system of a language's rules of grammar, its vocabulary, all the pieces of a language and how those pieces fit together".(Brown et.al.,) Based on this definition it is clear that competence about language emphasizes the rules of grammar, vocabulary and all the parts that are related to each other.

There are 4 (four) components or subcategories which contain components of a person's abilities related to language, namely: 1. Grammatical competence, contains knowledge of rational elements and morphological, syntactic, semantic, and phonological rules; 2 . Discourse competence, contains the ability to connect sentences so as to form discourse and to form the meaning of a series of utterances. Discourse means everything from simple conversations to long written discourses.; 3. Sociolinguistic competence, covering the sociocultural rules of language and knowledge of discourse. This competency requires an understanding of the social context in which the language is used which includes the role of each participant, the information discussed, and the interaction function; 4. Strategic competence, in the form of both verbal and nonverbal communication strategies that are used to eliminate barriers to communication both caused by lack of performance and lack of competence (Canale\&Swaim, 1980).

In learning English, there are 5 (five) proficiency levels in English: beginning, early intermediate, intermediate, early advanced, and advanced. The level of development of each level of English proficiency varies according to the characteristics of each student. 
The term strategy comes from the Greek "strategos" which means the overall effort which includes understanding the planning, methods and techniques used by the military to achieve victory in warfare (Hamalik, 1993).

Term strategy In the teaching and learning process, strategies can be interpreted as certain behaviors carried out by learners to achieve learning goals. One education expert provides a more detailed definition of learning strategies as "specific actions taken by the learner to make learning easier, faster, more enjoyable, more self-directed, more effective, and more transferable to new situations", which means certain actions done by learners to make learning easier, faster, fun, independent, effective, and more transferable to new situations.

An assessment of English language skills can be carried out during the teaching and learning activities or after the teaching and learning process has finished. Assessments during the learning process can use techniques such as Hughes's which consist of 2 (two) components, namely:

1) Understanding: the assessment of English language skills carried out focuses on contextual understanding of students.

2) Production (production): assessment during the learning process whose focus is the assessment of students' practices from what they understand contextually (Arthur, 2003).

\section{Teaching materials in learning English}

According to Ahmad Sudrajad, teaching materials are a set of material which are arranged systematically both written and not, so that an environment or atmosphere creates the ability for students to learn. Whereas according to Abdul Majid, teaching materials are all forms of materials, information, tools and texts that are used to help teachers / instructors in carrying out teaching and learning activities.

Teaching materials or learning materials generally consist of knowledge, skills, and attitudes that students must learn in order to achieve the competency standards that have been determined. In detail, the types of learning material consist of knowledge (facts, concepts, principles, procedures).

The development of teaching materials, including English language teaching materials, is an activity in the Research and Development (R \& $\mathrm{D})$ category. Gall \& Borg put forward 10 steps that must be taken in product development for learning. But Borg and Gall, who used Cunningham's research model, simplified the development process into six steps, namely:

1) Review the relevant literature about the textbook to be written.

2) Plan the purpose of each chapter or section.

3) Develop the initial draft

4) Test the initial draft on a limited number of subjects.

5) Revise the initial draft based on the results of the trial.

6) Test the revised draft based on the results of the first trial on a larger number of subjects (Borg \& Gall, 2003)

It is known that the purpose of preparing English language teaching materials is to facilitate teachers and students in the learning process. To achieve this goal Tomlinson presents the basic principles of acquiring a second language that are relevant to the development of material. The prepared teaching materials should be (Tomlinson, 1998) :

1) Has a positive impact, 
2) Make students feel comfortable,

3) Helping students develop self-confidence,

4) Students are seen as something relevant and useful,

5) Make students willing to try because they feel the benefits,

6) In accordance with the readiness or provision that students already have

7) Contains language features that should concern students,

8) Give students the opportunity to use English to achieve communicative goals,

9) Consider student differences in their learning styles and affective traits,

10) Consider the possibility of a period of silence (students may not be forced to speak) at the beginning of the learning period

11) Maximizing a variety of potential students by involving intellectual, aesthetic, and emotional intelligence that can stimulate the activity of the right brain and left brain.

\section{METHODOLOGY}

This study uses a descriptive approach with the aim of describing the object of research or the results of research. In the preliminary study phase a qualitative descriptive approach was applied. While at the development stage the model used a descriptive approach.

The understanding according to Sugiono is a method that serves to describe or give an overview of the object under study through data or samples that have been collected as they are, without analyzing and making general conclusions (Sugiyono,2012).

The type of research that will be used is research and development. The development model used in this study is a model developed by Sukmadinata in the Qualitative Research Methodology book, this model includes the development stage, namely preliminary study and model development (Moleong,2010).

This research was conducted at the Early Childhood Islamic Education (PIAUD) Study Program at the Tarbiyah and Teacher Training Faculty of UIN Mataram, having its address at Jalan Gajahmada Number 100, Mataram City. This location was chosen as a research setting because there was no specific type of training or course designed by study programs in improving English language skills of PIAUD Study Program students while English language competence was one of the main factors in improving the quality of PIAUD Study Program graduates.

There are 2 data used in this research (Sugiyono et.al.,) ; 1. Primary Data, which is the primary data in this study are students of PIAUD Study Program UIN Mataram Kindergarten and experts in teaching English; 2. secondary data, In this study the secondary data sources are literature, articles, journals and internet sites relating to research conducted

Research subjects

1. Population, The population used in this study were students of Mataram UIN PIAUD FTK whose English skills were at the beginner level of 285 (two hundred eighty five) people. 
2. Sample, Sample in this study amounted to 30 people. The sampling technique is using a random technique sampling.

Data collection methods used are:

1. Test

In this study, the intended English proficiency test was given twice, namely before taking the intensive course (pretest) and after taking the intensive course (posttest).

\section{Interview}

In this study, the interview was conducted 2 (two) times. The first interview conducted before the study began aimed at uncovering the supporting factors of learning and the second interview conducted on a subject in a limited trial study to uncover students' responses to the intensive course model developed as well as teaching materials prepared to support intensive coourse implementation.

3. Questionnaire

This questionnaire contains a series of questions / statements to reveal the subject's response to the intensive course model and instructional materials developed as well as criticisms and suggestions from respondents.

Data Analysis Method

1. Analysis of the results of the English language proficiency test

After giving a head test of all sample studies, the researcher then calculated the class average value which was then continued with the measurement of normalized gain by measuring the gain of students' scores before and after learning the teaching material with the following Hake normalized gain equation:

$$
\mathrm{G}=\frac{S_{\text {posttest }-} S_{\text {pretest }}}{S_{\text {maksimum }}-S_{\text {pretest }}}
$$

Test decision:

1. $\mathrm{g}$ is categorized as high if $(<\mathrm{g}>) \geq 0.7$;

2. $\mathrm{g}$ is categorized as moderate if $0.7>(<\mathrm{g}>) \geq 0.3$;

3. $\mathrm{g}$ is categorized as low if $(\langle\mathrm{g}\rangle)<0.3$

\section{Analysis of interview results}

The interview data were analyzed descriptively qualitatively to provide a detailed explanation of the obstacles experienced by students in studying the intensive course model and teaching materials as well as student opinions about the intensive course model and teaching materials being developed.

3. Questionnaire Analysis (Student Responses to Intensive Course Models and Teaching Materials)

In the analysis of this stage, data were obtained from the questionnaire scores of 
students' responses to the instructional materials given. The analysis was carried out by descriptive analysis. Student responses to teaching materials are obtained by determining the percentage of sub-variables according to the following equation:

$\mathbf{P}=\mathbf{x} / \mathbf{y} \times \mathbf{1 0 0}$

Information :

$\mathrm{P}=$ sub-variable percentage

$\mathrm{X}=$ number of values for each sub variable

$\mathrm{Y}=$ maximum score

The categories of student responses for each sub variable are as follows:

If $0 \%<$ score $\leq 25 \%$ is not good

If $26 \%<$ score $\leq 50 \%$ is not good

If $51 \%<$ score $\leq 75 \%$ is good enough

If $76 \%<$ score $\leq 100 \%$ is good

Test Validity / Validity of Data

Product validation in this study was carried out by presenting 2 (two) experts or experts who were experienced both in teaching English and in assessing new learning products that were designed. Each expert is asked to design the intensive course model and the instructional materials that have been prepared (the reviewer notes attached). Design validation in this study was carried out in a discussion forum, before the discussion researchers presented the assessment process until the design was found, along with its superiority.

\section{RESULT OF THE RESEARCH}

The results of the research at the initial stage indicate that the researcher is conducting a preliminary study which aims to obtain intensive intensive courses "which are intended to improve the ability of students at the Piaud FTK UIN Mataram program.

The first driver of learning is library studies, literature studies conducted by researchers and concepts related to intensive programs, as well as research results relating to intensive models to be developed. And the second is a field survey, At the survey stage, researchers did not get significant difficulties because the researchers themselves were secretaries of the FTK PIAUD Study Program at UIN Mataram. In addition, the researcher is also an instructor of English courses at the PIAUD Study Program. Fill in the information about whether there is an English language development program for PIAUD Study Program students. In terms of English language skills of students, researchers have gotten an overview of the scores of previous semester students. In this study the researchers also conducted a preliminary test (pretest) to see their initial abilities before intensive lecture courses.The third is the preparation of the initial product or the design of the intensive model only. Based on the data obtained from the studies, the researchers compiled an initial draft intensive program that was developed and also the development process. The fourth is Expert Test. The researcher conducted it with two experts and was accompanied by a research assistant at LesehanBebekGalih, which was located on the South Ring Road. Meetings are effective but relaxed by producing important notes including: An intensive course is held twice a week with a duration of 90 (ninety) minutes, The number of students in one class is 15-20 people, Teachers who will teach in the intensive course are professional lecturers using the prepared lesson courses.

After the preliminary study activities are completed, then proceed with the development of an intensive course model. 
The development of the intensive course model of teaching materials consists of two stages. The first is Limited trials, the intensive course model was tested on two predetermined students. The test subjects were PIAUD students whose English skills were at the beginner level. Second, a wider trial, a wider trial was conducted on 30 PIAUD students.

Teaching materials used in the Intensive Course PIAUD study program students scope preliminary studies. Another objective of conducting a preliminary study by the researcher was to make an initial draft design of the intensive course model which was then reviewed by an expert team before extensive development was carried out. The details of the stages of the preliminary study are as follows: (1) Literature review, literature studies conducted by researchers include searching and learning concepts or theories relating to the preparation of teaching materials and the results of previous studies relating to the model of instructional materials will be developed, (2) Field Survey, teaching materials used in the PIAUD Study Program are only textbooks published by the Language Development Center (P2B) Mataram UIN which are only intended for students who teach the Basic General Course (MKDU). Before the use of this teaching material was used a pretest. Based on the pre test scores obtained an average score of 70.1. The average of 70.1 for a maximum score of 100 is quite good, (3) Preparation of teaching materials initial products, based on data obtained from field surveys by referring to the basics of theory or concepts and the results of previous studies, the researcher compiled an initial draft of the teaching material developed and the development process, (4) Expert test. in this research, before the intensive course model is tested on an intensive course model, consulted experts who will test its feasibility. The expert test was carried out by researchers with two experts and accompanied by research assistants at Lesehan Bebek Galih, located on the South Ring Road. Meetings are effective but relaxed by producing important notes including: (a) There are materials that are changed in order so that the system can be better, (b) There are some materials that are too dense to teach only one meeting, so that they can be divided into two to three meetings, (c) A rating system must be added at the end of the course outline.

Development of Intensive Course Models and Teaching Materials, The trial development of the English language teaching material model consists of two stages: (1)Limited trials, the teaching materials are tested on two predetermined students. The test subjects were PIAUD students whose English skills were at the beginner level. The next step is the implementation of a limited trial with a small group consisting of 8 students randomly selected. Based on the results of the pre-test it is known that the average score of the two students' comprehension is 65 while the average post-test score is 90 . Based on the average score of the pre-test and post-test it is concluded that after learning the instructional materials given there is an increase in scores with gain 0,39 . This value is classified as moderate. (2) Small group trials, Based on the results of the pre test it is known that the average score of eight students is 69.1 while the average post-test score is 84. It is concluded that after learning the instructional materials given there is an increase in scores with gain of 0.21 gain score 0.21 is included in the low category. (3) Broader trials, wider trials were conducted on 30 PIAUD students. The Pre test value for this wider trial is 66.3 while the post test results are 84.6 so it can be 
concluded that the gain obtained is 0.28 . This 0.28 gain score is in the low category.

\section{DISCUSSION}

Regarding in Intensive Course Program in improving English skills Students of the FTK Piaud Study Program UIN Mataram. The intensive course model produced from this study is a model that considers the 5 (five) standards of intensive course implementation described by Djuju Sudjana. The coverage of these standards is: (a) Standard content, the content standard outlined includes the material and expected level of student competency after participating in the intensive course program. Besides that, in the intensive course model syllabus and lesson plans have been prepared that will be used as guidelines for the implementation of learning. The intensive course model is held 2 (two) times a week with a duration of 90 (ninety) minutes for each meeting. (b) Process standard, process Standards are national education standards relating to the implementation of learning in an educational unit to achieve the competency standards of graduates of English language courses. The intensive course model developed meets several aspects demanded by process standards, namely: (1) Lesson plansare arranged based on the number of planned meetings, which are 12 meetings. The first material is greeting, introducing oneself and others, this material is the simplest material. Then the second material continued with expressingopinions, like, and dislike material. (2)The number of students participatingin this intensive course is 30 (thirty) students whose English language skills are still at the beginner level. (c). Educator standards, In the implementation of the program the institution must also pay attention to the things in the criteria that educators must have such as educators must fulfill competencies that are in accordance with the standards set, must follow relevant quality improvement training. (d) Standard facilities and infrastructure, national education standards relating to minimum criteria about study rooms, places to exercise, places of worship, libraries, laboratories, places to create and recreation, as well as other learning resources, are needed to support the learning process, including the use of information technology and communication needed in an English course program. (e) Standard of assessment, the educational assessment standard is the national education standard relating to mechanisms, procedures, and instruments for the assessment of learning outcomes in English language courses.

Teaching Materials Used in the Intensive Course for PIAUD Study Program Students, the teaching materials produced in this study were in the form of two books, namely student's book and teacher's book with the following description: (a) Student's book, student's book is a teaching material book that is a guide and guidance for students in following the intensive course that has been designed.The 12 units included in the student's book are: (1)Lesson 1 greeting, introducing oneself and others. (2)Lesson 2 Expressing Opinion, like and dislike. (3)Lesson 3 Describing people, places, and things. (4) Lesson 4 making an appointment.

(5) Lesson 5 experessing wants and needs. (6) Lesson 6 makes offers and requests. (7) Lesson 7 expressing certainty and uncertainty. (8) Lesson 8 getting information.(9) Lesson 9 expressing agree and disagree. (10) Lesson 10 thanking people and repliying to thanks. (11) Lesson 11 making and accepting apology. (12) Lesson 12 making invitation. This teaching material in the form of student books has criteria as described by Tomlison that the criteria for good teaching materials are: Helping students develop self-confidence, students are seen as 
Jumrah, Developing An Intensive Course Model...

something relevant and useful, make students willing to try because they feel the benefits, in accordance with the readiness or provision that students already have, contains language features that should concern students, give students the opportunity to use English to reach communicative goals (footnote Tomlison). (a)Teacher's book, teacher's book is a guideline for each instructor in intensive course activities. Similar to the student book teacher's book consists of 12 units of material, all of which are exactly the same as what is in student books. However, teacher's book is equipped with instructions on how to teach each part in each unit.

\section{CONCLUSION}

Based on the results of the research steps above, it can be stated that this study has produced the final draft of English language teaching materials. Teaching materials compiled after being tested in the field have been shown to have a positive impact on improving students' English skills. Although the gain obtained by students is in the low category (in the trial of small groups and broader groups) and the medium category in the One on One trial, when viewed from the acquisition of values it can be stated that the teaching material is feasible because when viewed from the value obtained all students increase. The results of this study are still in accordance with Hake's opinion about normalized gain, namely the gain obtained from a very low to high score will be greater than the gain obtained from the high score to a higher score. Thus, the gain of 0.28 obtained from the pre test value of 66.3 and 84.6 post test has fulfilled the requirements to conclude that the instructional materials made have a positive impact on improving students' English skills.

\section{REFERENCES}

Abdulaiz, Alfehaid F.2017. Managing English Language Centers In The Uk Challenges And Implications. International journal of social scient and humanity, 6.(2), 15.

Arthur, Hughes.2003.Testing For Language Teachers 2 ed.Cambridege : Cambridge University Press.

Borg,W.R\& Gall, M.D.2003.Education Research : An Introduction. London: Seventh Edition.

Brown, H.G.2001.Teaching by Principles: Interactive Approach to Language Pedagogy.New York: San Francisco State University.

Canale, M. and Swain, M.1980.Theoretical bases of communicative approaches to second language teaching and testing. Canada:Applied linguistic.

Hamalik,Oemar.1993.StrategiBelajarMenga jar.Bandung: Mandar Manja.

Mustofa, K. (2012). Model Pendidikan dan Pelatihan. Bandung: Alfabeta.

Sri, A. (2012). PengenalanKosa Kata Bahasa Inggris Anak Usia Dini MelaluiNyanyian. Sciencedirect, 13(6), 23-24.

Sudjana, Djuju.2016.Manajemen Program Pendidikan Untuk Pendidikan Luar Sekolah dan PengembanganSumberDayaManusia . Bandung: Falah Production.

Tomlinson, B.1998.Materials Development in Language Teaching. Cambridge: Cambridge University Press. 
Jumrah, Developing An Intensive Course Model...

Tribunnews.com. (2017, September 29).

kemampuan bicara bahasa inggris masyarakat indonesia kurang. Retrived from tribunnews.com website:

http://www.tribunnews.com/nasional /2016/05/21/kemampuan-bicarabahasa-inggris-masyarakatindonesia-kurang 